\title{
A Synergism Induced by Satellite Panicum Mosaic Virus
}

\author{
Karen-Beth G. Scholthof \\ Department of Plant Pathology and Microbiology, Texas A\&M University, College Station 77843-2132, U.S.A. \\ Accepted 15 October 1998.
}

Panicum mosaic virus (PMV) induces a mild mottle on millet plants, but the addition of its satellite virus (SPMV) causes a severe chlorosis and stunting. Immunoblots, RNA blots, and sucrose density gradient analyses revealed increases of PMV RNA and its p8 and capsid proteins when plants were co-infected with SPMV. A unique feature associated with this satellite virus interaction was an increased rate of systemic infection of PMV.

Virus interactions resulting in a synergism have been described in association with many mixed virus infections, but particularly with potyviruses. A synergism is generally recognized as one virus acting as a catalyst to up-regulate the replication of a second, unrelated virus, resulting in more severe symptoms on the host (Goldberg and Brakke 1987; Pruss et al. 1997; Rochow and Ross 1955; Scheets 1998; Vance 1991; Vance et al. 1995). A synergism has also been reported with mixed infections of beet western yellows luteovirus and its ST9-associated RNA, which encodes a carmovirus-like replicase (Sanger et al. 1994). Although a satellite virus-associated synergism per se has not been reported, co-infections of tobacco mosaic virus (TMV) and its satellite virus, STMV, result in more severe symptoms on pepper plants than observed for TMV alone (Rodríguez-Alvarado et al. 1994).

Satellite panicum mosaic virus (SPMV) depends on its helper virus, panicum mosaic virus (PMV), for replication and movement. SPMV expresses a $17-\mathrm{kDa}$ capsid protein from its 826 nucleotide (nt) genome to form 16-nm icosahedral particles (Buzen et al. 1984; Masuta et al. 1987; Scholthof et al., in press). PMV, a single-stranded, positive-sense RNA virus of $4,326 \mathrm{nt}$ is the type member of the provisional genus Panicovirus within the Tombusviridae (Turina et al. 1998). A mixed infection of PMV and SPMV on St. Augustinegrass results in "St. Augustine decline," an economically important disease of St. Augustinegrass in the southern United States (Buzen et al. 1984; Holcomb et al. 1989; Scholthof et al. 1999). To investigate the biological complexity of the helpersatellite-host interactions in the Gramineae and the role of satellites as "molecular parasites," disease progression in pearl millet plants was monitored following inoculation with PMV or PMV+SPMV.

Corresponding author: Karen-Beth G. Scholthof; Telephone: 1-409-8458265; Fax: 1-409-845-6483; E-mail: kbgs@acs.tamu.edu
PMV-infected pearl millet plants generally are slightly stunted and the leaves display a mild chlorotic mottle (Fig. 1A). In contrast, PMV+SPMV infected plants develop chlorotic streaks on the emerging uninoculated leaves 3 to 4 days after the virus is first detected in the inoculated leaves; the symptoms rapidly progress to a severe chlorotic mottle with occasional regions of bleaching and/or necrosis. Mature plants and their panicles are severely stunted and rarely produce viable seed (Fig. 1B). To characterize the role of SPMV in this interaction, plants were monitored daily by immunoblot analyses to detect the capsid protein of PMV and SPMV. The PMV p8 protein, which is likely associated with cell-to-cell movement based on conserved similarity with the carmo- and necrovirus homologues (Turina et al. 1998), also was monitored by immunoblots.

A polyclonal antibody was derived to analyze PMV p8 protein in infected plants. To amplify the p8 open reading frame by PCR (polymerase chain reaction) from the fulllength infectious PMV cDNA clone, pPMV85 (Turina et al. 1998), a $5^{\prime}$ primer (5'-ATACGGATCCAATGTCTACTGTT$\left.3^{\prime}\right)$ was used to introduce a BamHI site (underline) just upstream of the predicted p8 start codon (nucleotides 2875 to 2877; double underline). The $3^{\prime}$ primer (5'-GTTGAGAACC CAGGAGCC- $3^{\prime}$ ) extended to a region downstream of the putative p8 stop codon. This PCR-derived DNA fragment was digested with the restriction enzymes BamHI and ScaI (PMV nucleotide 3149) and ligated in frame into the BamHI:SmaIdigested pGEX-1 vector (Pharmacia, Piscataway, $\mathrm{NJ}$ ) to create pKB137. Following transformation of Escherichia coli XL1 Blue (Stratagene, La Jolla, CA) with this construct, $1 \mathrm{mM}$ isopropyl- $\beta$-thiogalactopyranoside was added to induce the overexpression of a $34-\mathrm{kDa}$ glutathione S-transferase and $\mathrm{p} 8$ chimera (GST-p8). This GST-p8 protein was purified from sodium dodecyl sulfate (SDS)-polyacrylamide gels as described previously (Scholthof et al. 1994, 1995c) and a polyclonal antibody was prepared in New Zealand white rabbits (HTI BioProducts, San Ramon, CA).

PMV or PMV+SPMV RNA transcripts from cDNA were inoculated to pearl millet (Pennisetum glaucum) plants as described previously (Turina et al. 1998) and these primary infected plants were used as inoculum for subsequent experiments. Infected leaves were ground with a mortar and pestle in water (approximately 3:1 wt/vol) and inoculated onto two fully expanded leaves of young millet plants. Inoculated and upper uninoculated leaves pooled from three inoculated plants 
were collected at $3,4,5,6,7$, and 12 days post-inoculation (dpi) for protein assays.

To detect PMV and SPMV capsid proteins and PMV p8 protein, approximately $0.1 \mathrm{~g}$ of inoculated and $0.1 \mathrm{~g}$ of upper uninoculated leaves were pulverized separately in $1 \mathrm{ml}$ of TE (10 mM Tris, $1 \mathrm{mM}$ EDTA, pH 7.4) with $1 \mathrm{mM}$ dithiothreitol and disrupted in $2 \%$ SDS prior to boiling for $3 \mathrm{~min}$. The denatured samples were centrifuged for $5 \mathrm{~min}$ at $12,000 \times \mathrm{g}$ and equal volumes of supernatant were electrophoresed on $12.5 \%$ SDS-polyacrylamide gels. After electrophoretic transfer of the proteins to nitrocellulose membrane, antibodies specific to PMV and SPMV capsid proteins were used at dilutions of 1:20,000 and 1:10,000, respectively (Turina et al. 1998). An IgG-enriched fraction of the GST-p8 polyclonal antiserum was used at a dilution of 1:100. The details of protein preparation, immunoblots, and use of chemiluminescent substrate were described previously (Scholthof et al. 1994, 1995c; Turina et al. 1998).

At 3 dpi, very small amounts of the PMV and SPMV capsid proteins were detected in the inoculated leaves (Fig. 2). At 4 dpi both the PMV capsid and p8 proteins were detected at a higher titer in the mixed PMV+SPMV infection than for an infection with PMV alone. The most significant effect at $4 \mathrm{dpi}$ was the clear establishment of PMV+SPMV in upper uninoculated leaves, compared with the absence of detectable protein in PMV infection alone (Fig. 2). By 5 dpi, the PMV p8 and capsid proteins were readily detected in both single and mixed infections in the upper uninoculated leaves.

Later in the timecourse assay, at 7 and $12 \mathrm{dpi}$, the titer of $\mathrm{p} 8$ increased and was represented either as a dimer of $\mathrm{p} 8$ or perhaps as p8-FS (Fig. 2), a putative 14.6-kDa frameshift protein of p8 (Turina et al. 1998). On foxtail millet (Setaria italica cv. German R), both single and mixed infections showed a pattern of capsid and $\mathrm{p} 8$ protein accumulation similar to that on pearl millet (not shown).

On pearl millet, these immunoblot results were supported by total RNA extracts analyzed on 7.5 to $30 \%$ sucrose density gradients and RNA blots (Fig. 3). Sucrose density gradients, with an equivalent of $9.5 \mathrm{mg}$ of tissue per sample, were used to evaluate the chloroplast and cytoplasmic rRNA profiles as well as PMV and SPMV RNAs at 5, 7, and 10 dpi by a method previously described (Goldberg and Brakke 1987). Plants infected with PMV and PMV+SPMV consistently sustained a slight, but similar, reduction of rRNAs at 5 and 7 dpi (not shown), compared with healthy plant extracts. A small amount of PMV and SPMV was detected on the sucrose density gradients at $7 \mathrm{dpi}$. By $10 \mathrm{dpi}$, both PMV and PMV+SPMV infections resulted in similarly diminished levels of host rRNAs on systemically infected leaves when compared with the healthy rRNA profiles (Fig. 3A). The sucrose density gradient profiles also clearly show a small, yet consistent increase of PMV RNA, approximately two- to threefold, in association with SPMV vs the single infection (Fig. 3A). Total RNA was also extracted from plants for RNA blot analyses (Turina et al. 1998). The RNA blots confirmed that the PMV and SPMV RNAs defined in the sucrose density gradients are found in the upper uninoculated leaves (Fig. 3B).

These experiments suggest that the effect of SPMV shares classic features associated with a plant virus synergism, including increased virus titer, exacerbated symptoms, and more rapid systemic spread of the virus complex (Goldberg and
Brakke 1987; Pruss et al. 1997; Rochow and Ross 1955; Scheets 1998; Vance 1991; Vance et al. 1995). The potyvirusinduced synergism is associated with the HC-Pro domain, which perturbs the normal regulation of minus-strand RNA accumulation of the second virus (Pruss et al. 1997; Vance 1991). The unveiling of mechanisms associated with the upregulation of PMV by SPMV will be necessary to determine if it mimics the well-characterized, potyvirus-associated synergism. However, SPMV has some obvious differences from potyviruses and the ST9-associated RNA in that the satellite virus is completely dependent on PMV for both its replication and movement. In fact, one might expect SPMV to suppress
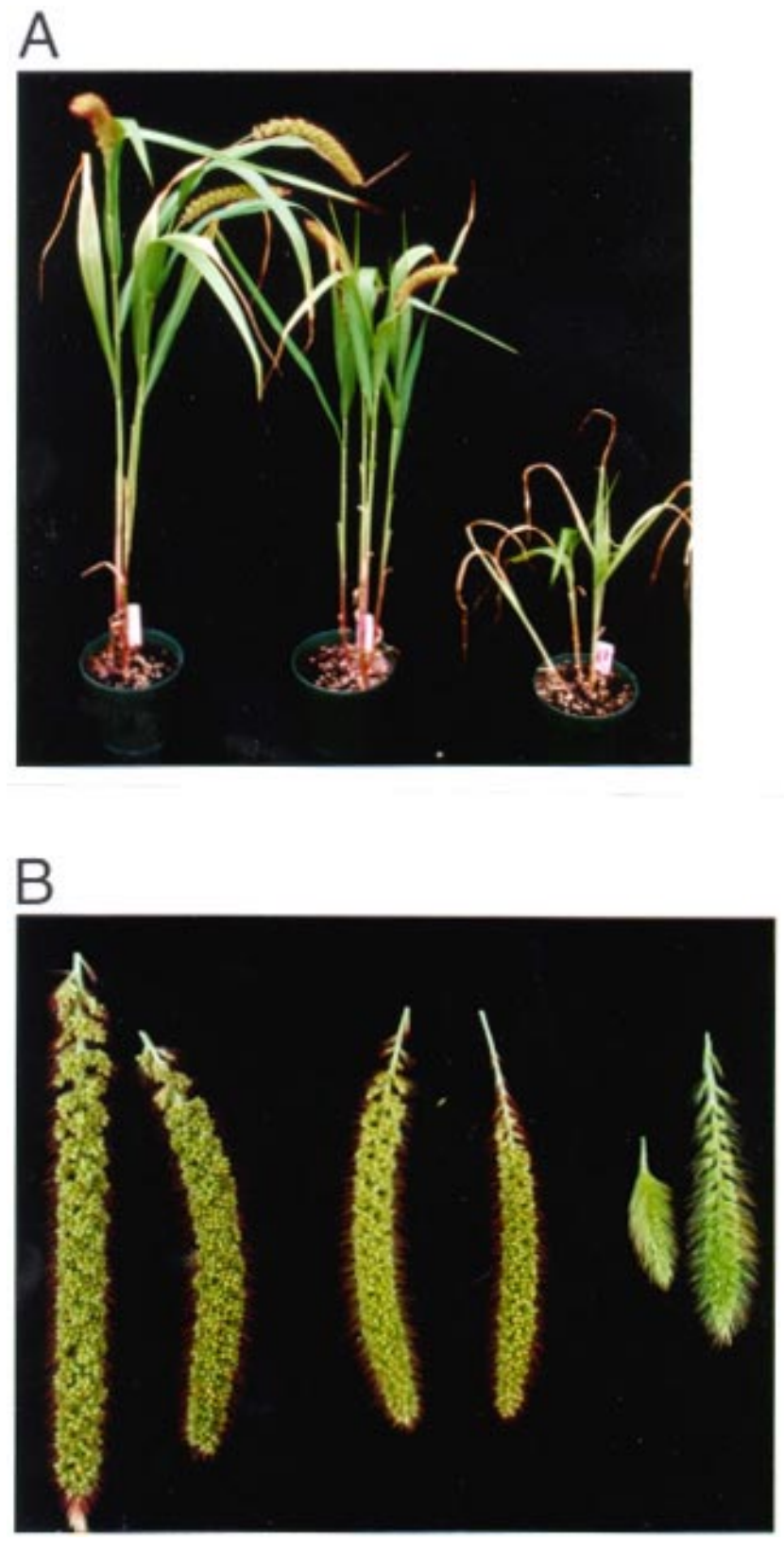

Fig. 1. Pearl millet plants infected with panicum mosaic virus (PMV) or both PMV and satellite PMV (SPMV) at 30 days post inoculation (dpi). Millet plants (A) and panicles (B) infected with PMV (center) or PMV+SPMV (right) at 30 dpi. Uninoculated controls are leftmost plant (A) and panicles (B). 
the helper virus titer and symptoms, as is observed with defective interfering RNAs and some satellite viruses (Roossinck et al. 1992; Scholthof et al. 1995b). Instead, a slight increase of at least two helper virus proteins, p8 and capsid protein, and the PMV RNA (Figs. 2 and 3) as well as more rapidly progressing disease are observed in PMV+SPMV infected millet plants (Fig. 1). Genetic and mutational analyses of PMV and SPMV are needed to elucidate the mechanisms that control this unique, satellite virusinduced, synergistic interaction. Recently, it has been shown that 34 nt from RNA-2 of red clover necrotic mosaic dianthovirus (RCNMV) can transactivate the accumulation of the RNA-1 subgenomic RNA (Sit et al. 1998). It is possible that SPMV RNA has a role in regulating the accumulation of the proteins encoded from the PMV subgenomic RNA, particularly in consideration of the early and more rapid movement in

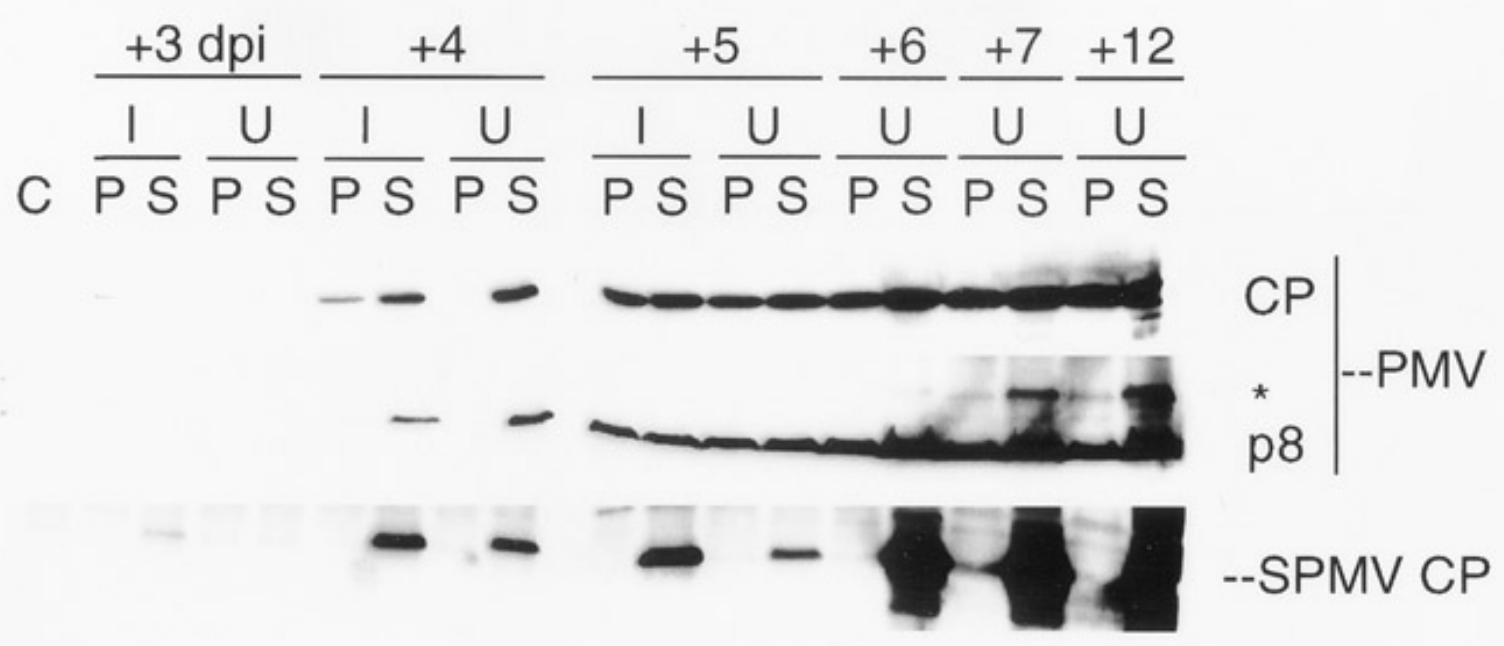

Fig. 2. Detection of panicum mosaic virus (PMV) capsid protein (CP) and p8 protein and satellite PMV (SPMV) CP in pearl millet plants. Leaves inoculated with PMV or PMV+SPMV were assayed at 3 to 5 days post inoculation (dpi) and upper uninoculated leaves were collected at 3 to 7 and 12 dpi. Total proteins were extracted, disrupted in $2 \%$ sodium dodecyl sulfate (SDS), and electrophoresed through 12.5\% SDS-polyacrylamide gels with either Tris-glycine (for CP) or Tris-tricine (for p8) buffer systems as described previously (Turina et al. 1998). Proteins were transferred to nitrocellulose membranes, blocked with nonfat dry milk, and incubated with the primary antibody overnight. Secondary antibody (goat anti-rabbit HRP) was added for 2 to $4 \mathrm{~h}$ followed by addition of a chemiluminescent substrate and visualization on X-ray film. Indicated above the panels: the dpi, inoculated (I) and upper uninoculated (U) leaves, and inoculation with PMV (P) or PMV+SPMV (S). Antibodies used for specific detection of PMV CP, PMV p8, and SPMV CP are noted to the right of each panel. Asterisk $\left(^{*}\right)$ above $\mathrm{p} 8$ protein reflects either a protein dimer of $\mathrm{p} 8$ or the putative PMV p8-FS product of approximately 14.6 kDa (Turina et al. 1998).

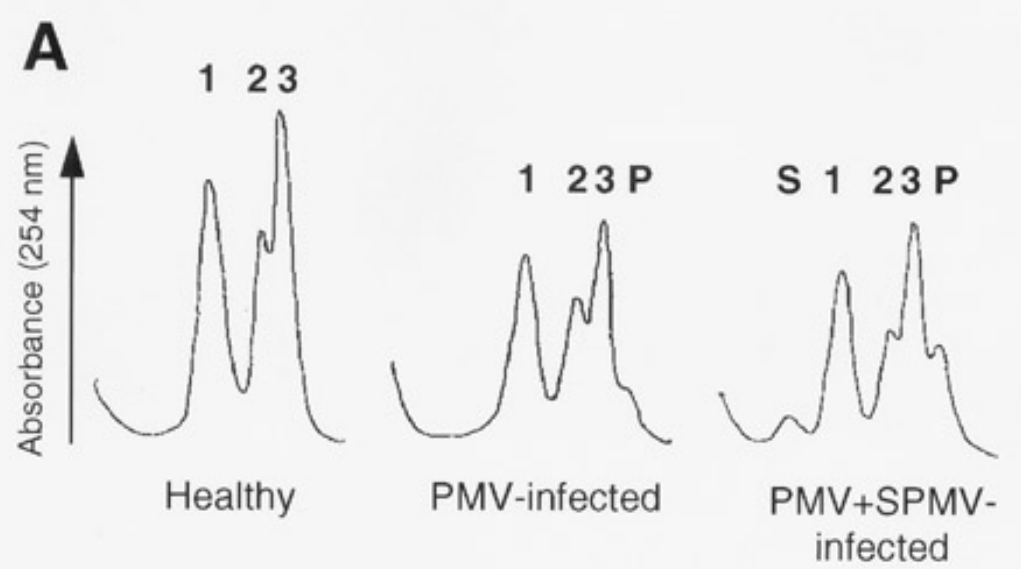

B

Fig. 3. Sucrose density gradients and RNA blot analyses of total RNA extracts from pearl millet plants 10 days post inoculation (dpi) with panicum mosaic virus (PMV) or both PMV and satellite PMV (SPMV). A, Absorbance scans (254 nm) of 7.5 to 30\% sucrose density gradients in NaGPS buffer $\left(0.05 \mathrm{M} \mathrm{Na}_{2} \mathrm{HPO}_{4}, 0.3 \mathrm{M} \mathrm{NaCl}, 0.1 \mathrm{M}\right.$ glycine, and $1 \mathrm{mM}$ EDTA, $\left.\mathrm{pH} 9.4\right)$ following centrifugation at 54,000 rpm for $3 \mathrm{~h}$ at $15 \mathrm{C}$ in an SW60 rotor (Beckman, Fullerton, CA) (Goldberg and Brakke 1987). Total RNA from systemically infected and healthy millet leaves was extracted in 0.1 M $\left(\mathrm{NH}_{4}\right)_{2} \mathrm{CO}_{3}, 0.3 \mathrm{M} \mathrm{NH}_{4} \mathrm{Cl}, 1 \mathrm{mM}$ EDTA, and 1\% sodium dodecyl sulfate, $\mathrm{pH} 9.4$ (Goldberg and Brakke 1987). Peak 1 represents $16 \mathrm{~S}$ and $18 \mathrm{~S}$ rRNAs; peak 2, the 23 S rRNA; peak 3, the 28 S rRNA. Peaks P and S represent PMV and SPMV RNAs, respectively. B, RNA blots of inoculated (I) and upper uninoculated (U) millet leaves infected with PMV (P) or PMV+SPMV (S). Total RNA was extracted from plants at 10 dpi and electrophoresed through duplicate $1 \%$ agarose gels prior to transfer to nylon membrane. The membranes were incubated overnight with ${ }^{32} \mathrm{P}$-labeled probes specific to the pPMV85 or pSPMV1 full-length cDNA clones and autoradiographed at $-80^{\circ} \mathrm{C}$ for $4 \mathrm{~h}$. The origin of the RNA band (denoted by asterisk) running slightly ahead of the 826 nucleotide SPMV RNA is unknown. Location of PMV and SPMV RNA is indicated on right side of panel. 
association with the accumulation of $\mathrm{p} 8$, a putative PMV movement protein (Fig. 2). Alternatively, or additionally, the SPMV capsid protein may be directly involved in exacerbation of symptom development, possibly akin to the effects of the gene VI protein of caulimoviruses (Goldberg et al. 1991) or the p19 protein of tomato bushy stunt virus (Scholthof et al. 1995a).

Two possible mechanisms have been proposed to understand plant virus synergisms (Goldberg and Brakke 1987; Rochow and Ross 1955). A synergism may induce a higher concentration of virus in each cell, possibly due to a perturbation of normal cellular regulation. Within this framework, it is tempting to speculate that SPMV may suppress or interfere with host defense responses, as recently described for the potyvirus system (Anandalakshmi et al. 1998). Alternatively, more cells may be infected, which suggests that the synergism facilitates cell-to-cell movement or perhaps "relaxes" the celltype specificity. Evaluation of the data associated with the accumulation of the helper and satellite virus capsid proteins and PMV p8 suggests that more rapid cell-to-cell spread of PMV may result in a greater percentage of cells infected in the upper uninoculated leaves, and an increase in titer as the infection progresses (Figs. 2 and 3). The rRNA profiles indicate that the PMV and PMV+SPMV infections have similar effects on the host chloroplast and cytoplasmic ribosomes. Therefore, the severe systemic symptoms associated with SPMV appear to be due to yet undetermined effects on the host cell that apparently do not differentially modify the rRNA profiles. Elucidation of the means by which SPMV affects both the helper virus and the host plant may provide us with new strategies to control an economically important disease complex associated with St. Augustinegrass and other monocotyledonous host plants.

\section{ACKNOWLEDGMENTS}

Joan Kuecker and Beth Whitehead provided much-appreciated technical assistance. Herman Scholthof, Massimo Turina, WenPing Qiu, and Jeffrey S. Batten are gratefully acknowledged for helpful discussions and critical reviews of the manuscript. Moreover, I appreciate the interesting discussions on virus synergism with Ed Anderson. I also thank Gene Perry of Perry Brothers Seed (Otis, CO) for providing the German $\mathrm{R}$ millet seed. Funding was provided by the Texas Agricultural Experiment Station (H-8388) and USDA Competitive Grant 96-35303-3714.

\section{LITERATURE CITED}

Anandalakshmi, R., Pruss, G. J., Ge, X., Marathe, R., Mallory, A. C., Smith, T. H., and Vance, V. B. 1998. A viral suppressor of gene silencing in plants. Proc. Natl. Acad. Sci. USA 95:13079-13084.

Buzen, F. G., Jr., Niblett, C. L., Hooper, G. R., Hubbard, J., and New- man, M. A. 1984. Further characterization of panicum mosaic virus and its associated satellite virus. Phytopathology 74:313-318.

Goldberg, K.-B., and Brakke, M. K. 1987. Concentration of maize chlorotic mottle virus increased in mixed infections with maize dwarf mosaic virus, strain B. Phytopathology 77:162-167.

Goldberg, K.-B., Kiernan, J., and Shepherd, R. J. 1991. A disease syndrome associated with expression of gene VI of caulimoviruses may be a nonhost reaction. Mol. Plant-Microbe Interact. 4:182-189.

Holcomb, G. E., Liu, T. Z., and Derrick, K. S. 1989. Comparison of isolates of panicum mosaic virus from St. Augustinegrass and centipedegrass. Plant Dis. 73:355-358.

Masuta, C., Zuidema, D., Hunter, B. G., Heaton, L. A., Sopher, D. S., and Jackson, A. O. 1987. Analysis of the genome of satellite panicum mosaic virus. Virology 159:329-338.

Pruss, G., Ge, X., Shi, X. M., Carrington, J. C., and Vance, V. B. 1997. Plant viral synergism: The potyviral genome encodes a broad-range pathogenicity enhancer that transactivates replication of heterologous viruses. Plant Cell 9:859-868.

Rochow, W. F., and Ross, A. F. 1955. Virus multiplication in plants doubly infected by potato viruses $\mathrm{X}$ and Y. Virology 1:10-27.

Rodríguez-Alvarado, G., Kurath, G., and Dodds, J. A. 1994. Symptom modification by satellite tobacco mosaic virus in pepper types and cultivars infected with helper tobamovirus. Phytopathology 84:617621.

Roossinck, M. J., Sleat, D., and Palukaitis, P. 1992. Satellite RNAs of plant viruses: Structures and biological effects. Microbiol. Rev. 56: 265-279.

Sanger, M., Passmore, B., Falk, B. W., Bruening, G., Ding, B., and Lucas, W. J. 1994. Symptom severity of beet western yellows virus strain ST9 is conferred by the ST9-associated RNA and is not associated with virus release from the phloem. Virology 200:48-55.

Scheets, K. 1998. Maize chlorotic mottle machlomovirus and wheat streak mosaic rymovirus concentrations increase in the synergistic disease corn lethal necrosis. Virology 242:28-38.

Scholthof, H. B., Scholthof, K.-B. G., and Jackson, A. O. 1995a. Identification of tomato bushy stunt virus host-specific symptom determinants by expression of individual genes from a potato virus $\mathrm{X}$ vector. Plant Cell 7:1157-1172.

Scholthof, K.-B. G., Hillman, B. I., Modrell, B., Heaton, L. A., and Jackson, A. O. 1994. Characterization and detection of sc4: A sixth gene encoded by sonchus yellow net virus. Virology 204:279-288.

Scholthof, K.-B. G., Jones, R. W., and Jackson, A. O. 1999. Biology and structure of plant satellite viruses activated by icosahedral helper viruses. Curr. Top. Microbiol. Immunol. 239:123-143.

Scholthof, K.-B. G., Scholthof, H. B., and Jackson, A. O. 1995b. The effect of defective interfering RNAs on the accumulation of tomato bushy stunt virus proteins and implications for disease attenuation. Virology 211:324-328.

Scholthof, K.-B. G., Scholthof, H. B., and Jackson, A. O. 1995c. The tomato bushy stunt virus replicase proteins are coordinately expressed and membrane associated. Virology 208:365-369.

Sit, T. L., Vaewhongs, A. A., and Lommel, S. A. 1998. RNA-mediated trans-activation of transcription from a viral RNA. Science 281:829832.

Turina, M., Maruoka, M., Monis, J., Jackson, A. O., and Scholthof, K.B. G. 1998. Nucleotide sequence and infectivity of a full-length cDNA clone of panicum mosaic virus. Virology 241:141-155.

Vance, V. B. 1991. Replication of potato virus X RNA is altered in coinfections with potato virus Y. Virology 182:486-494.

Vance, V. B., Berger, P. H., Carrington, J. C., Hunt, A. G., and Shi, X. M. 1995. 5' proximal potyviral sequences mediate potato virus X/potyviral synergistic disease in transgenic tobacco. Virology 206:583-590. 